\title{
Breeding and alimentation in the roman cisalpina: a first balance between archaeology and zoo- archaeology from high ground and valley floor villages
}

\begin{abstract}
The report aims to offer a preliminary framework of knowledge on zoo-archaeological topics in the North-Eastern Italy during the Roman age, through a comparative data analysis from high ground and valley floor villages. The purpose is also connecting archaeological and zoo-archaeological data with other kind of source, if possible. The faunistic data show the prevalence of ovine and pigs, related to environmental vocation and also political, economical and cultural influences in the complex relation among production, distribution and consumption.
\end{abstract}

Keywords: North east Italy (cisalpina), roman age, zoo-archaeology, breeding, diet
Volume 3 Issue I - 2018

\section{Buglione Antonietta}

Department of Humanistic Studies, Università degli studi di Foggia, Italy

\section{Correspondence: Buglione Antonietta, Department of Humanistic Studies, Università degli studi di Foggia, Italy, Email antoniettabuglione@gmail.com}

Received: July 29, 2017 | Published: January II, 2018

\section{Introduction}

This paper intends to offer an evaluation of the animal resource and the food habits in high ground and valley floor villages in the North-Eastern Italy during the Roman age (1st-6th c AD), connecting zoo-archaeological and archaeological data from some edited archaeological contexts, often separated and not updated (for a more extensive framework of knowledge) ${ }^{1,2}$ In fact it is necessary to insert the preliminary zoo-archaeological data in a more and ample complex historical and archaeological context. Besides, it is possible highlight the informative potentiality of this kind of research and the necessity to connect the zoo-archaeological remains and the other resources for a geographical and chronological area of interest that only recently has known this approach.

\section{Case presentation}

The sheep (Ovis aries) breeding is prevalent in the high ground villages such as Monte Sorantri di Raveo $(890 \mathrm{~m})$, in the region called Carnia, in I-II c AD (Figure 1). Sheep were used for meat and fat, as it is evident from individuals killed between two and four years old. $63 \%$ of the bones belong to sheep respect to a minor percentage of goats (Capra hircus). The kind of remains indicates a primary butchery (mandibles, jaws, skulls, teeth) and consumption (ribs and vertebras) that happened in the site. Probably, the so-called containers Auerberg were produced and used for this resource, because the archaeometrical analysis reveals that fat could be inside used to waterproof the vase in the production phase, or to avoid the freezing in the high sites. More probable the fat was contained in the vase. The big size of the animals, comparable with roman ones from Aquileia, for example, could indicate a specialization of the ovine breeding in high ground settlements, connected to the seasonal movements of herds from the Friulian region plains to the mountain areas of Carnia: Monte Sorantri probably represents an alpine pasture post in the summer.

A prevalence of sheep for wool and meat purpose is also evident in the close settlements of Colle Mazèit di Verzegnis $(400 \mathrm{~m})$ and on Monte Castellir di Elleri, near Trieste $(215 \mathrm{~m})$. The same is evident at Castelraimondo village $(400 \mathrm{~m})$, where zoo-archaeological data for I-II c AD reveal an interest for sheep breeding, for meat and cheese products. This activity was conforming to the hilly site. Probably also pig (Sus scrofa) was bred in wild way and butchered in the site, considering the presence of all the skeleton As regards to plain settlements, a similar management of domestic animals, with a prevalence of sheep used for meat, is evident in the S Candido village $(1250 \mathrm{~m})$, where there are also bovine remains, killed in adult age, probably used as work-force; in the valley floor village of Bressanone-Stufles (560m) (Dominick e Senoner), from I to V c AD, cows (Bos taurus) and pigs are only secondary resources. Cow is very big, similar to Altino and Aquileia ones and we can argue it represents a roman race, but there are also bone remains from small size ones, probable local race of the Late Antiquity. The site of Stufles Senoner seems a summer grazing-ground, but several elements suggest that limited transhumance took place at Stufles. Mackinnon ${ }^{2}$ supposed that the pattern about adult sheep and goat's predominance was connected to short-distance transhumance where ewes might have greater prominence than to long-distance operations that emphasize raising wethers and rams for wool. ${ }^{2}$

Instead at Volano (Trento), cows were very important, both as food and work resource in farming. Considering these data, it is possible to argue that sheep breeding was the principal resource of high ground and valley floor villages, thanks to many uncultivated and different areas, appropriate to pastoral breeding. The prevalence of cows is associated with a big rural connotation of the settlements at inferior quota, such as at Volano. Another interesting aspect to consider is the absence of wild remains, perhaps due to a limited access to hunting by population. A major balance between bovines and sheep is evident in the roman settlements of Egna (Bolzano I-III c AD), associated with the mansio Endidae dell'Itinerarium Antonini along the Claudia Augusta Altinate via, between Trento and Bolzano. Bones were collected in a kitchen and in a well, probably food remains. It is interesting that pig bones are almost absent, suggesting local tradition in the diet. The influence of environment and local traditions shows its force also analyzing the data from minor settlements in the 
plain, called Calvatone (CR), the ancient vicus Bedriacum. If in the settlements datable to Augustean and Tiberian age sheep is prevalent, used for wool and meat, with pigs, after and until V-VI c AD. We can observe a different trend with the prevalence of pigs and sheep used for meat production, with a breeding near the house.

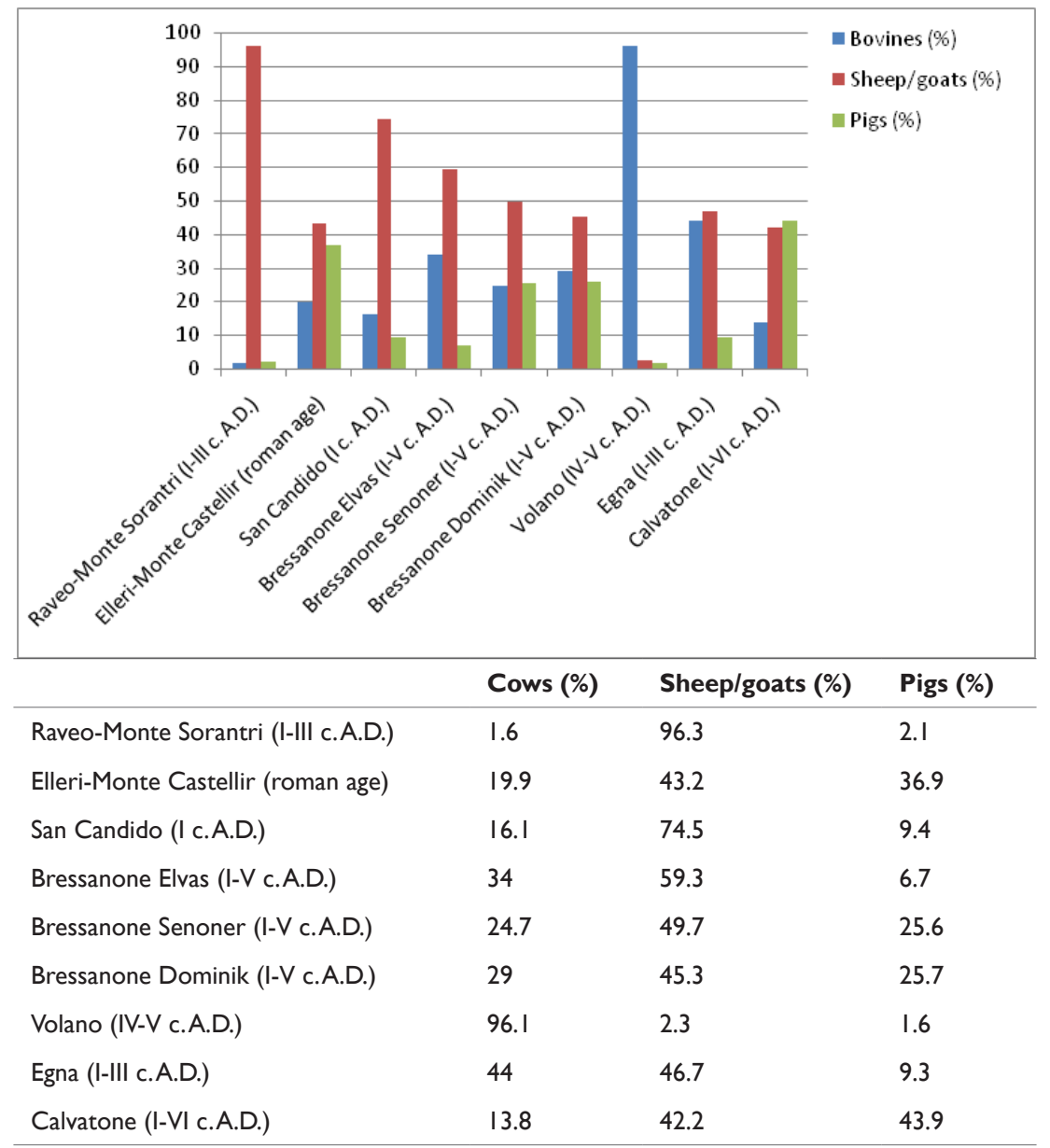

Figure I Percentages of animals used in the diet.

\section{Discussion}

The faunistic data show the prevalence of ovine and pigs in Roman Cisalpina and in the sites here considered (Table 1), ${ }^{3-14}$ connected with environmental vocation and also with political, economical and cultural influences in the complex relation among productiondistribution- consumption. ${ }^{1}$ The zoo-archaeological trend of enhanced sheep production in Northern Italy accords with Columella's comments about the importance of this region for wool production and therefore the northern Italian sheep were improved to produce better-quality wool than most southern Italian breeds. ${ }^{2}$ According to zoo-archaeological data, Invillino-Ibligo seems to be a summer grazing ground for caprines: dental data here show a predominance of deaths in the 7-12 month category, while sex data report slightly more females than males. Some studies on pig measurements from Alpine sites suggest that attention was paid to feeding and raising pigs such as at Stufles and Invillino-Ibligo settlements; besides it is possible to argue an annual breeding and culling schedule, with summer births and early winter culls.

Table I Contexts analyzed in this paper with number of bone remains (NISP) and percentages

\begin{tabular}{|c|c|c|c|c|c|c|c|c|}
\hline Site & Province & Context & Cronology & Nisp & $\%$ Cow & \% Sheep/goat & $\%$ Pig & Bibliography \\
\hline \multicolumn{9}{|l|}{ Friuli-venezia giulia } \\
\hline Castelraimondo & UD & high ground village & I-II cAD & n.d & & & & Petrucci 3-5 \\
\hline Verzegnis-Mazèit & UD & high ground village & Roman age & n.d & & & & Petrucci 3-5 \\
\hline Raveo-Monte Sorantri & UD & high ground village & I-III c AD & 575 & $\mathrm{I}, 6$ & 96,3 & 2,1 & 6 \\
\hline Elleri-Monte Castellir & TS & high ground village & Roman age & 236 & 19,9 & 43,2 & 36,9 & $3,4,7$ \\
\hline \multicolumn{9}{|l|}{ Trentino alto adige } \\
\hline Volano & $\mathrm{TN}$ & valley floor village & $I V-V c A D$ & 308 & 96,1 & 2,3 & $\mathrm{I}, 6$ & 8 \\
\hline
\end{tabular}


Table Continued....

\begin{tabular}{|c|c|c|c|c|c|c|c|c|}
\hline Site & Province & Context & Cronology & Nisp & \% Cow & \% Sheep/goat & $\%$ Pig & Bibliography \\
\hline Egna & $B Z$ & valley floor village & I-III c AD & 1015 & 44 & 46,7 & 9,3 & 9 \\
\hline S. Candido-Innichen & $B Z$ & high ground village & I $c A D$ & 721 & 16,1 & 74,5 & 9,4 & Riedel 10 \\
\hline $\begin{array}{l}\text { Bressanone-Elvas } \\
\text { Kreuzwiese }\end{array}$ & $B Z$ & valley floor village & $\mathrm{I}-\mathrm{V}$ cAD & 923 & 34 & 59,3 & 6,7 & Boschin, et al. I I \\
\hline $\begin{array}{l}\text { Bressanone-Stufles } \\
\text { Senoner }\end{array}$ & $B Z$ & valley floor village & $\mathrm{I}-\mathrm{V}$ cAD & 1506 & 24,7 & 49,7 & 25,6 & 12,13 \\
\hline $\begin{array}{l}\text { Bressanone- Stufles } \\
\text { Dominik }\end{array}$ & BZ & valley floor village & $\mathrm{I}-\mathrm{V} c \mathrm{AD}$ & 1128 & 29 & 45,3 & 25,7 & 12,13 \\
\hline \multicolumn{9}{|l|}{ Lombardia } \\
\hline Calvatone/Bedriacum & $C R$ & Plane village & $\mathrm{I}-\mathrm{VI} \mathrm{c} A \mathrm{AD}$ & 419 & 13,8 & 42,2 & 43,9 & 14 \\
\hline
\end{tabular}

\section{Acknowledgements}

I thank MS Busana of Padua University for getting involved in this first balance and also S Garavello of Venice University for our interesting conversations, for her zooarchaeological studies in Northern Italy and for the table 1.

\section{Conflict of interest}

Author declares there is no conflict in publishing the article.

\section{References}

1. Busana MS, Buglione A, Garavello S. Gestione degli animali e alimentazione nella Cisalpina romana tra archeologia e archeozoologia in L'alimentazione nell'antichità. XLVI Settimana di Studi Aquileiesi. 2016. p. $305-322$.

2. Mackinnon M. Production and consumption of animals in Roman Italy: integrating the zooarchaeological and textual evidence. In: Humphrey $\mathrm{JH}$, editor. UK; Journal of roman archaeology supplementary series number fifty-four. 2004. p. 264

3. Petrucci G, Petrucci G. Sfruttamento della fauna nel territorio di Aquileia: trasformazione, consumoe distribuzione dei prodotti. I dati dell'archeozoologia. Antichità Altoadriatiche. 2007;65(2):755-782.

4. Petrucci G. I dati archeozoologici dai siti del Friuli Venezia Giulia. In: Ventura P, et al. editor. P L'allevamento ovino e la lavorazione della lana nella parte orientale della Regio X: testimonianze materiali, resti archeitettonici, archeozoologia, in La lana nella Cisalpina romana. 2012 p. 183-187.
5. Petrucci G (in press) La fauna di Castelraimondo (scavi 1999-2005). Castelraimondo III Scavi 1999-2005, a cura di S Santoro, Roma.

6. Petrucci G, Donat P, Vitri S. La fauna di et à primo-medio imperiale dal sito d'altura di Raveo. In: Malerba G, Visentini P, editors. Monte Sorantri (Carnia UD): analisi preliminare, in Atti del $4^{\circ}$ Convegno Nazionale di Archeozoologia, Italy; 2005. p. 325-330.

7. Petrucci G. La fauna protostorica e romana. Il Civico Museo archeologico di Muggia, Trieste; 1997. p. 121-132.

8. Riedel A, Scarpa G. Resti animali di un complesso produttivo di età tardoromana a Volano. Annali del Museo Civico di Rovereto. 1988;4:37-54.

9. Riedel A, Tecchiati U. I resti faunistici della Mansio Romana di Endidae sulla via Claudia Augusta. Archäologie der Römerzeit in Südtirol. 2002. p. 318-336.

10. Riedel A. Tierfunde einer römischen Fundstätte von Innichen. Padusa 1983;19:3-18.

11. Boschin F, Weissteiner M. Una casa datata alla prima età romana imperiale scavata a Elvas presso Bressanone. Annali del Museo Civico diRovereto. 2008;23:3-34.

12. Riedel A. Die Fauna einer frühmittelalterlichen Siedlung in Stufel bei Brixen. Der Schlern. 1979;53(7):3-23.

13. Riedel A. Die fauna von zwei römischen Fundstätten im Brixner Gemeindegebiet. Der Schlern. 1984;58(8):455-498.

14. Baker P, Martino S. I reperti faunistici, in Bedriacum. Ricerche archeologiche a Calvatone, 12 Il Campo del Generale: i materiali del saggio 6, Italy; 1996. p. 29-47. 